\title{
$\mathrm{LR}=$ INTERNATIONAL JOURNAL OF ACADEMIC \\ HUMAN RESOURCE
MAAAGEMENACADEMIC
RESEARCH SOCIETY

\section{Heuristic Based Low Volatility Portfolio for Retail Investors in Malaysian Stock Market}

Siti Masitah Elias, Muhd Faiz Najmi Abdul Wahab, Karmila Hanim Kamil and Asmah Mohd Jaapar

To Link this Article: http://dx.doi.org/10.6007/IJARAFMS/v10-i3/7756

DOI:10.6007/IJARAFMS /v10-i3/7756

Received: 10 July 2020, Revised: 30 July 2020, Accepted: 24 August 2020

Published Online: 28 September 2020

In-Text Citation: (Elias, Abdul Wahab, Kamil, \& Jaapar, 2020)

To Cite this Article: Elias, S. M., Abdul Wahab, M. F. N., Kamil, K. H., and Jaapar, A. M. (2020). Heuristic Based Low Volatility Portfolio for Retail Investors in Malaysian Stock Market . International Journal of Academic Research in Accounting, Finance and Management Sciences. 10(3), 193-203.

\section{Copyright: (c) 2020 The Author(s)}

Published by Human Resource Management Academic Research Society (www.hrmars.com)

This article is published under the Creative Commons Attribution (CC BY 4.0) license. Anyone may reproduce, distribute, translate and create derivative works of this article (for both commercial and non-commercial purposes), subject to full attribution to the original publication and authors. The full terms of this license may be seen at: http://creativecommons.org/licences/by/4.0/legalcode

Vol. 10, No. 3, 2020, Pg. 193 - 203

Full Terms \& Conditions of access and use can be found at http://hrmars.com/index.php/pages/detail/publication-ethics 


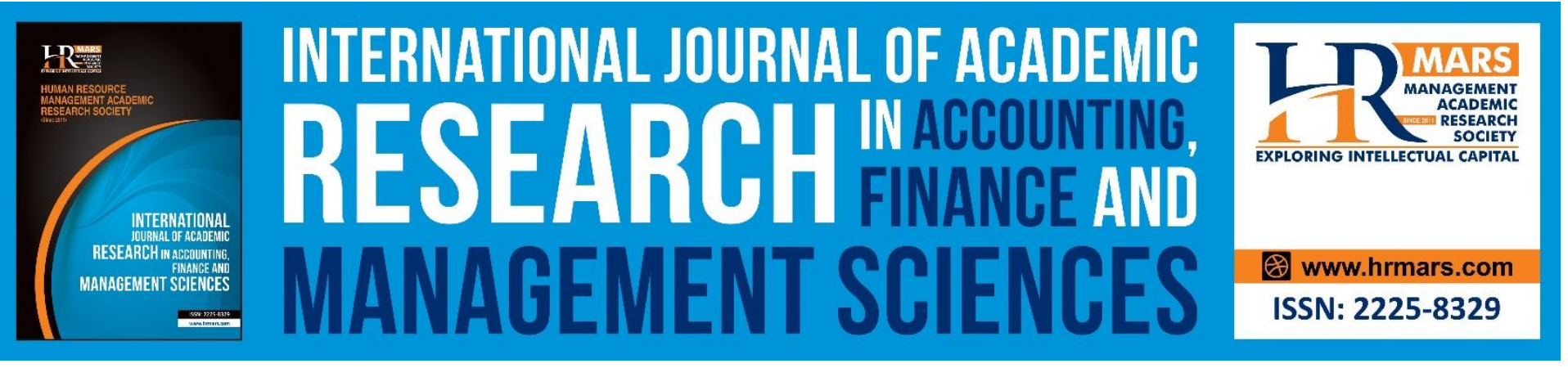

\title{
Heuristic Based Low Volatility Portfolio for Retail Investors in Malaysian Stock Market
}

\author{
Siti Masitah Elias, Muhd Faiz Najmi Abdul Wahab, Karmila Hanim \\ Kamil and Asmah Mohd Jaapar \\ Financial Mathematics Program, Faculty of Science and Technology, Universiti Sains Islam Malaysia, \\ 71800 Bandar Baru Nilai, Negeri Sembilan, Malaysia \\ Email: masitah@usim.edu.my
}

\begin{abstract}
Heuristics based low volatility portfolio construction is a straightforward investment strategy that could be implemented by retail investors in the stock market. This study examines the performance of low volatility portfolio for Shariah and conventional stock portfolios. Specifically, this study back tests the profitability of low volatility portfolio using 15 Shariah and conventional stocks that are listed on Bursa Malaysia using data from January 2014 until December 2018. Combination of large, mid, and small capital firms are included in the study to highlight the difference in portfolio concentration within firm size classification. The results show that, the return of conventional portfolio and shariah compliant portfolio is not statistically different. However, the risk in shariah compliant portfolio is statistically higher than the conventional portfolio. Both portfolios give better annualized return and holding period return than their respective benchmark. Thus, retail investor could take advantage of the strategy to generate abnormal return. For investors that focus on shariah compliant investment only, even though the portfolio has slightly higher risk than the conventional counterpart, this strategy is still worth considering. However, it is advisable for investor to monitor portfolio risk regularly to avoid excessive risk taking and to include more shariah compliant large cap stocks in the portfolio.
\end{abstract}

Keywords: Low Volatility Portfolio, Shariah Compliant Stock, Retail Investor.

\section{Introduction}

Malaysian stock market has witnessed a steady rise on the participation of retail investors in stock trading especially among the millennials. In 2016, there is a $36 \%$ jump in the number of Central Depository System (CDS) opened by people with age 25 years and below in Malaysian capital market (Aruna, 2017). This trend is still continuing in 2019 as more than $40 \%$ of CDS accounts were opened by the youngsters (Ooi, 2019). However, due to various economics and political challenges that has been faced by Malaysia in recent years, stock investors especially those with limited trading experience need to equip themselves with the appropriate knowledge especially in managing their stock portfolios. The lack of knowledge on the return expectation and risk inherent in the stock 
INTERNATIONAL JOURNAL OF ACADEMIC RESEARCH IN ACCOUNTING, FINANCE AND

MANAGEMENT SCIENCES

Vol. 10, No. 3, 2020, E-ISSN: 2225-8329 @ 2020 HRMARS

market could be catastrophic towards portfolio value. Evidently, Malaysian National Strategy for Financial Literacy 2019-2023 has highlighted that most investors have unrealistic return and risk estimation in the stock market. Therefore, more research and study on stock investment that focuses on retail investors is crucially needed.

When investing in the stock market, retail investors need to answer two important questions. Firstly, they need to know when to enter and exit the stock market. Secondly, they need to decide on what are the stocks to be included in their portfolio. Focusing on the stock selection strategies, there have been various investment strategies that sprouted from the tenets of technical and fundamental analysis. The ability of the strategies to give abnormal profit to investors is known as market anomaly and has been discussed quite extensively under the area of behavioural finance (Woo et al., 2020). Complexity of the strategies vary, and new investor could easily be overwhelmed by the vast choices.

The proponents of low volatility portfolio believe that low volatility stocks will continue to exhibit low volatility characteristics in the future. Chow et al. (2014) stated that there are two main approaches in the selection of low volatility portfolios, namely the minimum variance-based portfolios and the heuristic-based portfolios. The minimum variance-based portfolio has been studied in Jaaman \& Lam (2012); Elias et al. (2014); Lee et al. (2016) and Bin \& Yuan (2016) for Malaysian stock market. More specifically, Nadhirin et al. (2020) apply minimum variance-based portfolio to shariah compliant portfolio construction in Malaysia. The low volatility portfolio, based on heuristics methodology, performs comparatively and slightly better than the minimum variance in various markets (Chow et al., 2014). Apart from minimum variance portfolio and heuristic based low volatility portfolio, Kim (2018) utilises regression-based volatility forecasting method to construct low volatility portfolio.

The result from Kim (2018) shows that the regression based low volatility portfolio outperforms the respective benchmark. There is also evidence that shows low volatility stocks could give better return to investors (Blitz \& Van Vliet, 2007; Blitz \& Vidojevic, 2017). Furthermore, Blitz et al. (2013) developed a decile portfolio based on three-year realized volatility. In this research, low volatility stocks displayed low beta and high- volatility stocks exhibited high beta. The risk of the stock as measured by standard deviation, is therefore exhibit the same pattern when measured with beta.

Volatility of a stock could also be associated with the market capitalisation of the stock. Wyatt (2009) asserts that small cap stocks are often not as liquid as larger stocks. Due to the illiquidity of many small cap stocks, the share prices tend to be more volatile. This implies that small cap share prices will increase and fall faster and with greater magnitude as compared to large cap stock. Therefore, this study aims to include stocks from various market capitalisation class to be incorporated in the stock selection strategies following the heuristics based low volatility portfolio formation. This study will also shed light on profitability of heuristics based low volatility portfolio for retail investors by limiting the number of stocks in observation to take into consideration allocated time in making investment decision as most retail investors are not active investors unlike institutional investors. Since this study focuses on retail investors, heuristics based low volatility portfolio formation will be utilised due to its simplicity and straightforwardness. Furthermore, shariah compliant and conventional portfolios will be constructed in this study considering that Malaysian 
INTERNATIONAL JOURNAL OF ACADEMIC RESEARCH IN ACCOUNTING, FINANCE AND

MANAGEMENT SCIENCES

Vol. 10, No. 3, 2020, E-ISSN: 2225-8329 @ 2020 HRMARS

market consists of these two group of retail investors. Thus, the objectives of this study are; 1 ) to construct heuristic based low volatility portfolios in Malaysian stock market, 2) to measure the performance of the constructed portfolios and, 3) to compare the performance of conventional and shariah compliant portfolios.

\section{Data and Methodology}

In this study, FTSE Bursa Malaysia Emas Index (FBME) and FTSE Bursa Malaysia Emas Shariah Index (FBMES) is adopted as the benchmark for conventional and shariah portfolio respectively. Besides, the daily 3-month KLIBOR (Kuala Lumpur Interbank Offered Bank) is used to be risk free rate proxy. Individual stock prices will also be utilised in this study for portfolio construction and performance measurement.

\section{Stock Screening}

Fifteen individual stocks from conventional and Shariah compliant companies are screened to be included in the portfolio. The stock that are selected must be the constituent of large, mid and small cap index in Malaysia with five stocks will be selected from each market cap group. In addition, the criteria of stocks that have chosen are mostly below RM 10, from well-known company and actively traded in the stock market. The daily stock prices are collected from January 2014 until December 2018.

The selected stock in this study is presented in table 1 . There are redundancies in the selected stock for both portfolios. It is because, in conventional portfolio, investors are free to invest in any stock without any restrictions. Meanwhile, for shariah compliant stocks, it is prohibited to invest in stocks that are not qualified as shariah compliant. However, in Malaysia, almost $80 \%$ of the listed stocks are shariah compliant which still offer great diversification benefits for shariah investors.

Table 1. Selected stocks for conventional and shariah compliant portfolio based on market capitalisation

\begin{tabular}{|l|l|l|}
\hline Market Caps & Conventional Portfolio & Shariah Compliant Portfolio \\
\hline \multirow{4}{*}{ Large Caps } & Public Bank & Axiata \\
\cline { 2 - 3 } & Malayan Bank & Digi \\
\cline { 2 - 3 } & Tenaga Nasional & Tenaga Nasional \\
\cline { 2 - 3 } & CIMB & Maxis \\
\cline { 2 - 3 } & Petronas & Petronas \\
\hline \multirow{5}{*}{ Mid Caps } & Gamuda & Gamuda \\
\cline { 2 - 3 } & IJM & IJM \\
\cline { 2 - 3 } & Telekom & Telekom \\
\cline { 2 - 3 } & BATO & Westport Holding \\
\cline { 2 - 3 } & QL Resources & QL Resources \\
\hline \multirow{5}{*}{ Small Caps } & Muhibbah Engine & Muhibbah Engine \\
\cline { 2 - 3 } & Ta Enterprise & Ta Enterprise \\
\cline { 2 - 3 } & Ta Ann Holding & Ta Ann Holding \\
\cline { 2 - 3 } & Frontken & Frontken \\
\cline { 2 - 3 } & Uchi Tech & Uchi Tech \\
\hline
\end{tabular}


INTERNATIONAL JOURNAL OF ACADEMIC RESEARCH IN ACCOUNTING, FINANCE AND

MANAGEMENT SCIENCES

Vol. 10 , No. 3, 2020, E-ISSN: 2225-8329 @ 2020 HRMARS

\section{Portfolio Construction and Backtesting}

In this study, heuristic based low volatility portfolio will be constructed and backtested for the chosen time period. Data will be divided into 10 subperiods to allow semi-annual portfolio revision. In the first subperiod, which is from January 2014 until June 2014, the volatility of the 15 stocks will be calculated and ranked from the lowest to the highest. Next, stock portfolio will be constructed which consist of 5 stocks with the lowest standard deviation. The stocks are assumed to be invested in the next subperiod (July 2014 until December 2014) for back testing. This investment process will be repeated until 9 portfolios are constructed and back tested. The inclusion of 5 stocks during each subperiod is in line with Benjelloun \& Abdullah (2009) which indicates at least 5 stocks will be used for an individual investor to get diversification benefit.

\section{Portfolio Performance Measurements}

The performance of the back tested portfolio will be measured using various portfolio performance measurement. The daily return and holding period return (HPR) are calculated and geometrically linked for each subperiod. The final values will be annualised to give better indication on the performance. The daily standard deviation is also computed and annualised for both portfolios. Apart from that, Beta, Sharpe ratio, Jensen Alpha and Treynor ratio are provided to allow better portfolio performance comparison. Finally, T-test and F-Test are conducted to examine the difference in mean daily return and daily return standard deviation for conventional and shariah compliant portfolio.

\section{Result and Discussion}

In this study, heuristics based low volatility portfolio for Malaysian stock market is implemented and the return for both conventional and shariah compliant portfolio is compared. This will shed light on the profitability of this strategy to be implemented by retail investors.

\section{Stock Volatility and Market Capitalisation}

Individual stock volatility plays a major role in determining overall portfolio risk. Apart from that, the correlation between one stock to another will also contribute towards portfolio overall risk. The gist of modern portfolio theory originated by Markowitz (1972) is to find portfolio allocation that maximizes return per unit of risks. Heuristics based low volatility portfolio on the other hand, simplifies the model by focusing only on the individual stock volatility while disregarding correlation between stocks. The simplicity of this model is the main attraction especially for retail investors.

As being highlighted by Wyatt (2009), listed companies with large market capitalisation should have lower volatility as compared to small companies. This pattern could also be observed in this study. Figure 1 shows the average annualised standard deviation for 5 stocks in each market size segment and the benchmark indices. Highest volatility level could be detected in small cap stocks for both conventional and shariah compliant portfolio with annualised standard deviation of $35.08 \%$. Meanwhile, large cap stocks recorded $16.82 \%$ and $19.31 \%$ annualised price variation for conventional and shariah compliant stocks, respectively. As expected, the market benchmarks give the lowest volatility mainly due to large number of constituents for each index that drives volatility very low. 
Vol. 10, No. 3, 2020, E-ISSN: 2225-8329 @ 2020 HRMARS

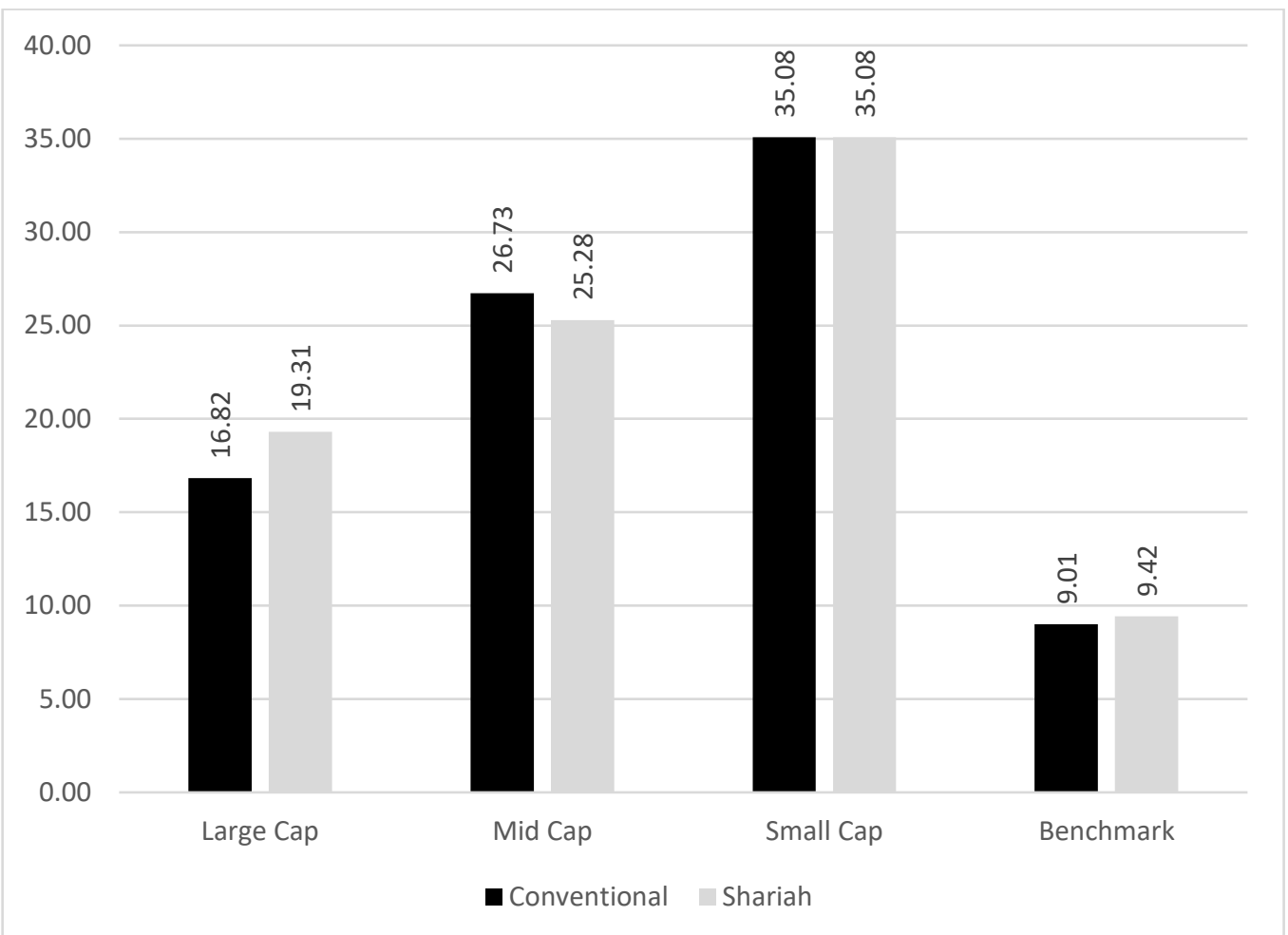

Figure 1. Average Annualised Standard Deviation for Selected Stocks from Jan 2014 until Dec 2018 (\%)

\section{Portfolio Construction}

Following heuristic based low volatility portfolio construction, for each in sample subperiod, individual stock volatility will be ranked and 5 stocks with the lowest volatility will be invested equally in the next out of sample subperiod. The stocks will be held for 6 months and at the end of the holding period, the stocks will be liquidated to allow semi-annual portfolio revision. This periodic rebalancing strategy is selected to avoid large transaction costs when shorter rebalancing period is implemented.

Based on the results, it can be observed that each portfolio constitutes mostly with large cap stocks. From all 9 subperiods, only one includes stock from the small cap. This highlights the importance of large cap stocks inclusion in the portfolio to manage risk (Wyatt, 2009). For conventional portfolio, Public Bank stock is selected for every subperiod. Meanwhile, companies that are frequently selected for shariah compliant portfolio are Tenaga Nasional and Digi Berhad. All companies that have been frequently selected are blue-chip companies which is mainly due to its stability and strong fundamentals. The inclusion of on more blue-chip stocks in the portfolio for efficient diversification due to its superior performance is supported by Zaimovic et al. (2020). 
INTERNATIONAL JOURNAL OF ACADEMIC RESEARCH IN ACCOUNTING, FINANCE AND MANAGEMENT SCIENCES

Vol. 10, No. 3, 2020, E-ISSN: 2225-8329 @ 2020 HRMARS

Table 2. Portfolio allocation for each subperiod based on market capitalisation

\begin{tabular}{|l|l|l|l|l|l|l|}
\hline \multirow{2}{*}{$\begin{array}{l}\text { Sub } \\
\text { period }\end{array}$} & \multicolumn{3}{|l|}{ Conventional Portfolio } & \multicolumn{3}{l|}{ Shariah Compliant Portfolio } \\
\cline { 2 - 7 } & Large Cap & Mid Cap & Small cap & Large Cap & Mid Cap & Small cap \\
\hline 1 & 4 & 1 & & 4 & 1 & \\
\hline 2 & 3 & 2 & & 3 & 2 & \\
\hline 3 & 2 & 3 & & 3 & 2 & \\
\hline 4 & 3 & 2 & & 3 & 2 & \\
\hline 5 & 3 & 2 & & 2 & 3 & \\
\hline 6 & 3 & 2 & & 3 & 2 & \\
\hline 7 & 3 & 1 & 1 & 2 & 2 & 1 \\
\hline 8 & 4 & 1 & & 4 & 1 & \\
\hline 9 & 4 & 1 & & 4 & 1 & \\
\hline
\end{tabular}

\section{Portfolio Performance}

To back test the constructed portfolio in the out of sample period, the Holding Period Return (HPR) is computed. Table 3 shows that HPR for both portfolios are mostly positive as compared to their respective benchmark. During the first subperiod, conventional portfolio recorded the lowest HPR with $-11.98 \%$. Meanwhile, the lowest HPR occurred during the second subperiod for shariah compliant portfolio with $-7.25 \%$. The highest HPR for both portfolios are recorded for the seventh subperiod. Cumulative HPR is calculated to get better view on the long-term portfolio performance. Overall, both portfolios outperformed against their respective benchmark. For the period of study, Malaysian financial markets are experiencing various challenges; economically and politically. Therefore, it was reflected in the negative cumulative an annualised HPR value for both benchmarks. Despite these challenges, the strategy implemented in this study manage to generate better HPR than the benchmark which is quite captivating for retail investors. 
INTERNATIONAL JOURNAL OF ACADEMIC RESEARCH IN ACCOUNTING, FINANCE AND MANAGEMENT SCIENCES

Vol. 10, No. 3, 2020, E-ISSN: 2225-8329 @ 2020 HRMARS

Table 3. Holding Period Return (HPR) for Conventional and Shariah Compliant Portfolio (\%)

\begin{tabular}{|l|l|l|l|l|}
\hline \multirow{2}{*}{$\begin{array}{l}\text { Sub } \\
\text { period }\end{array}$} & \multicolumn{2}{|l|}{ Conventional Portfolio } & \multicolumn{2}{l|}{ Shariah Compliant Portfolio } \\
\cline { 2 - 5 } & Portfolio HPR & Benchmark HPR & Portfolio HPR & Benchmark HPR \\
\hline 1 & -11.98 & -7.39 & 3.46 & -6.32 \\
\hline 2 & -2.30 & -2.19 & -7.25 & -2.05 \\
\hline 3 & -2.60 & -1.19 & -0.25 & 2.98 \\
\hline 4 & 3.17 & -0.27 & -2.11 & -3.55 \\
\hline 5 & -3.79 & -0.17 & -4.29 & -0.34 \\
\hline 6 & 6.64 & 10.00 & 6.65 & 6.66 \\
\hline 7 & 18.09 & 2.47 & 15.76 & 3.46 \\
\hline 8 & 9.45 & -6.75 & 0.61 & -8.21 \\
\hline 9 & 6.20 & -3.28 & 4.47 & -4.87 \\
\hline $\begin{array}{l}\text { Cumulative } \\
\text { HPR }\end{array}$ & 21.72 & -9.46 & 16.39 & -12.47 \\
\hline $\begin{array}{l}\text { Annual } \\
\text { HPR }\end{array}$ & 4.46 & -2.17 & 3.43 & -2.92 \\
\hline
\end{tabular}

Table 4 shows performance measurement for both portfolios with their respective benchmark. This calculation is obtained from low volatility portfolio daily return for the period July 2014 until December 2018. The annualised daily average return for both portfolios are significantly higher than the market benchmark. Annualised daily average return for conventional portfolio is $1 \%$ higher than the shariah compliant portfolio. Two sample T-test confirms that there is no significant evidence to suggest that the mean return for both portfolios is unequal. This finding contradicts with Hussin et al. (2018). Meanwhile, standard deviation of the portfolios are more than four times the standard deviation of the benchmark. This level of risk is compensated with a higher return level. Volatility is significantly higher for shariah compliant portfolio following the results from two sample F-test.

The value of beta for both portfolios are negative which indicates the low volatility portfolios move in the opposite direction from the overall market movement (Tarantino, 2010). Although it is quite rare to get portfolio with negative beta, the constructed portfolios show otherwise. It indicates that the investment strategy could offer a hedge against market downturns. The low volatility conventional portfolio slightly outperforms the shariah portfolio for Sharpe and Jensen measures. The Treynor ratios for both portfolios are negative due to the negative Beta values. 
INTERNATIONAL JOURNAL OF ACADEMIC RESEARCH IN ACCOUNTING, FINANCE AND

MANAGEMENT SCIENCES

Vol. 10, No. 3, 2020, E-ISSN: 2225-8329 @ 2020 HRMARS

Table 4. Performance of Conventional and Shariah Compliant Portfolio (p-value is indicated in parentheses)

\begin{tabular}{|l|l|l|}
\hline & $\begin{array}{l}\text { Conventional } \\
\text { Portfolio }\end{array}$ & $\begin{array}{l}\text { Shariah Compliant } \\
\text { Portfolio }\end{array}$ \\
\hline Benchmark Return & $-2.40 \%$ & $-3.00 \%$ \\
\hline Benchmark Std Dev & $9.30 \%$ & $9.66 \%$ \\
\hline Annualized Return & $30.93 \%$ & $\begin{array}{l}29.93 \% \\
(0.973)\end{array}$ \\
\hline Annualized Std Dev & $41.67 \%$ & $\begin{array}{l}45.63 \% \\
(0.001) *\end{array}$ \\
\hline Beta & & -0.3179 \\
\hline Sharpe & -0.1296 & 0.5883 \\
\hline Treynor & 0.668 & -0.8445 \\
\hline Jensen & -2.1477 & 0.249 \\
\hline
\end{tabular}

*indicates $5 \%$ level of significance for the difference between conventional and shariah compliant portfolio

The superiority of conventional and shariah compliant portfolio is still being debated in the finance literature (Hussein \& Omran, 2005). Reddy \& Fu (2015) reported that Shariah stock is riskier as compared to the conventional stock. In this study, the results show that the comparison of low volatility strategy performance for conventional and Islamic portfolio give the same return for both portfolios but possess different risk level. Even though the study finds that shariah compliant portfolio has greater risk than conventional portfolio, it could be mitigated by increasing the number of stocks in the portfolio to reap more diversification benefit and reduce portfolio risk. Furthermore, shariah compliant investor could also focuses on stocks with large market cap.

\section{Conclusion}

Low volatility portfolio is constructed to take advantage of individual stock price stability over time. This study back tests the profitability of low volatility portfolio with semi-annual rebalancing over the study period. The portfolio is constructed by monitoring 15 stocks at a time and invested in 5 of the stocks in every investment period. Furthermore, investors are assumed to revise their portfolio semi-annually. The focus of this study is for retail investors in conventional and shariah compliant stock portfolios.

The implementation of this trading strategy is quite straight forward and could be considered even for novice investors. As compared to Nadhirin et al. (2020), this study utilises a simpler strategy and could still outperform the market benchmark. It is however very crucial for investor to manage their portfolio wisely and monitor their portfolio every now and then to take advantage of the market inefficiencies. 
INTERNATIONAL JOURNAL OF ACADEMIC RESEARCH IN ACCOUNTING, FINANCE AND MANAGEMENT SCIENCES

Vol. 10 , No. 3, 2020, E-ISSN: 2225-8329 @ 2020 HRMARS

The contributions of this study are threefold. Firstly, it shows that most large cap stocks are less volatile and should be included in investors' watchlist to select stock. Secondly, the study indicates that Malaysian market is possibly not weak form efficient as the technical analysis that has been carried out in this study manage to provide abnormal return to investors. Finally, the statistical test shows that the return of shariah compliant portfolio is equal to the conventional portfolio. Thus, a slightly smaller number of stocks investable by shariah compliant investor in Malaysian stock market does not have significant impact on portfolio return and could still provide diversification benefit for retail investors. However, shariah compliant portfolio exhibits higher risk than the conventional portfolio. Frequent monitoring is suggested to ensure that risk level is within investors' acceptable level and investors could include more large cap companies in their selection to reduce risk level. It is suggested that for further research, different rebalancing period could be tested with the incorporation of transaction costs to compensate a more frequent trading.

\section{Acknowledgement}

This research was supported by Universiti Sains Islam Malaysia short grant (Project code: PPP-FST10617-00).

\section{References}

Aruna, P. (2017). More young investors entering into Malaysian market. The StarBiz Online. Retrieved from https://www.thestar.com.my/business/business-news/2017/05/03/young-investors/

Benjelloun, H., and Abdullah, A. M. (2009). Index funds and diversification in Saudi Arabia. International Journal of Islamic and Middle Eastern Finance and Management, 2 (3), 201-212.

Bin, R. L., and Yuan, C. J. (2016). Portfolio Diversification Strategy in the Malaysian Stock Market. Capital Markets Review, 24 (1), 38-67.

Blitz, D., and Van Vliet, P. (2007). The volatility effect. The Journal of Portfolio Management, 34 (1), 102-113.

Blitz, D., and Vidojevic, M. (2017). The profitability of low-volatility. Journal of Empirical Finance, 43, 33-42.

Blitz, D., Pang, J., and Van Vliet, P. (2013). The volatility effect in emerging markets. Emerging Markets Review, 16, 31-45.

Chow, T. M., Hsu, J. C., Kuo, L. L., and Li, F. (2014). A Study of Low-Volatility Portfolio Construction Methods. The Journal of Portfolio Management, 40 (4), 89-105.

Elias, S. M., Razak, M. Z., \& Kamil, K. H. (2014). Investment strategies in Malaysian Shariah-compliant equities with transaction costs. 'Ulūm Islāmiyyah Journal, 13, 179-196.

Hussein, K., and Omran, M. (2005). Ethical investment revisited: evidence from Dow Jones Islamic indexes. The Journal of Investing, 14 (3), 105-126.

Hussin, S. A. S., Saring, N., Zahid, Z., and Ramli, N. A. (2018, July). Performance of low volatility shariah equities in Malaysia. In AIP Conference Proceedings (Vol. 1982, No. 1, p. 020026). AIP Publishing LLC.

Jaaman, S. H., and Lam, W. H. (2012). Mean-variance and mean-Gini analyses to portfolio optimization in Malaysian stock market. Economic and Financial Review, 2 (2), 60-64. 
INTERNATIONAL JOURNAL OF ACADEMIC RESEARCH IN ACCOUNTING, FINANCE AND

MANAGEMENT SCIENCES

Vol. 10, No. 3, 2020, E-ISSN: 2225-8329 @ 2020 HRMARS

Kim, S. (2018). Volatility forecasting for low-volatility portfolio selection in the U.S. and the Korean equity markets. Journal of Experimental \& Theoretical Artificial Intelligence, 30 (1), 71-88.

Lee, H. S., Cheng F. F., and Chong S. C. (2016). Markowitz portfolio theory and capital asset pricing model for Kuala Lumpur stock exchange: A case revisited. International Journal of Economics and Financial Issues, 6 (3S):59-65.

Nadhirin, N. F. S. M., Ishak, N., and Elias, S. M. (2020). Performance of Shariah-Compliant Equity Portfolio Using Model-Based Return and Risk Estimation. Journal of Economic Info, 7 (2), 104119.

Ooi, T. C. (2019). More millennials investing in the stock market. New Straits Times. Retrieved from https://www.nst.com.my/business/2019/08/510296/more-millenials-investing-stock-market

Reddy, K., and Fu, M. (2014). Does shariah compliant stocks perform better than the conventional stocks? A comparative study of stocks listed on the Australian Stock Exchange. Asian Journal of Finance \& Accounting, 6 (2), 155-170.

Tarantino, A. (2010). Essentials of risk management in finance. John Wiley \& Sons.

Wyatt, I. (2009). The Small Cap Investor: Secrets to Winning Big with Small Cap Stocks. John Wiley \& Sons.

Woo, K. Y., Mai, C., McAleer, M., and Wong, W. K. (2020). Review on efficiency and anomalies in stock markets. Economies, 8 (1), 20.

Zaimovic, A., Arnaut-Berilo, A., and Osmanbegovic, A. (2020). Efficient Diversification with ShariahCompliant Stocks: Evidence from the South-East European Capital Markets. In Islamic Finance Practices (pp. 111-129). Palgrave Macmillan, Cham. 